\title{
An Analysis of Impolite Words among Makassarese Youngsters
}

\author{
Srirahayu Putri' ${ }^{1)}$, Andi Syurganda ${ }^{2}$, Nur Mutmainna Halim ${ }^{3)}$ \\ ${ }^{1}$ Universitas Islam Makassar \\ srirahayuput@gmail.com \\ ${ }^{2}$ Universitas Islam Makassar \\ andisyurganda@gmail.com \\ ${ }^{3}$ Universitas Islam Makassar \\ nurmuthhlm@yahoo.com \\ Received: $28^{\text {th }}$ October 2021| Revised: $29^{\text {th }}$ November 2021| Accepted: $27^{\text {th }}$ December 2021 \\ Email Correspondence: nurmuthhlm@yahoo.com
}

\begin{abstract}
This research aims: 1) to find out impolite words found among Makassarese youngsters 2) to find out how the impolite words are conversed and exchanged among Makassarese youngsters. The method of research used in this research is a qualitative descriptive method, which is used to analyze data from the research participants, namely Makassarese youngsters. The data obtained are impolite words in the conversations Makassarese youngsters, then analyzed by using Brown \& Levinson's politeness theory. Based on the results of that research, it shows that in the conversations Makassarese youngsters, there are some impolite words such as sundala, kongkong, pottele, tolo, ka'bulamma and telang spoken by subjects of this research. The use of these impolite words is usually exchanged by youngsters in their local community, such as close friends, also in family or even other environments that supports the situation. The use of impolite words among Makassarese youngsters is generally practiced as an opening word or conversation, while the duration of starts from the beginning of the conversation until the end of the conversation.
\end{abstract}

Keywords: impolite words, youngsters, makassarese

\section{INTRODUCTION}

Language is a means of communication. Every language in the world has rules that bind its users in using that language. In everyday life, the use of language usually follows the prevailing norms. Two of the regional languages in South Sulawesi are Buginese and Makassarese. Central Statistics Agency (BPS) in 2020 recorded that the current population of South Sulawesi is more than nine million. With a breakdown of the number of residents living based on the family register of people, it reaches 7.4 million people. Meanwhile, there are 1.6 million people who do not live based on the family register. This

Online at https://journal.universitasbumigora.ac.id/index.php/humanitatis/

DOI : https://doi.org/10.30812/humanitatis.v8i1.1533 
indicates that there is a large number of language users in the area. Thus, it is important to pay attention to the norms or rules that apply in each region (Sehe, 2021).

Angelina (2011) identifies youngsters as a social category whose meaning is formed based on a certain context. Therefore, youngsters is not a universal definition. However, things differ according to time and space. The notion of youngsters is also influenced by social, political, cultural and economic contexts. Wyn \& White (1997) stated that society is also determined by a person's gender, class, caste, race, level of education, or ethnicity. The used of impolite language among youngsters sometimes offend people. In Makassar setting, these youngsters often used this impolite language in public places where for some people is rude. The speech used by youngsters contains harsh words, insults, and so on. It is not uncommon for these youngsters to argue with by exchanging harsh words. On the other hand, the existence of a linguistic phenomenon like this is certainly an interesting thing to observe. The researcher choses the analysis of the used of impolite language among Makassarese youngsters by considering the used of impolite language among youngsters. This research aims to find out the speech of Makassarese youngsters which contains language rudeness by paying attention to the speech that is carried out by them.

The use of harsh and impolite words in language is not recommended because it has a bad meaning. Nevertheless, along with the development of technology, it is found that the used of impolite language is used more frequently. Tasliati (2018) said that especially among youngsters, its used in daily interactions is seen as a form of close friendship, or emotional connection. Based on the results of observations, the researcher found several places in Makassar where language can be used as a medium to find out a person's personality, or to measure how norms social in the area affect community can the whole. In this research, the researcher looks for utterances that are considered impolite among Makassarese youngsters. This research is also conducted to determine how impolite words are pronounced and how it is exchanged among Makassarese youngsters. With the current covid-19 pandemic, which affects various aspects of social life, it is certainly a challenge for researcher to consider the interests of research and to maintain the purity of the data taken. It is conducted while complying with recommended health protocols such as wearing masks, washing hands, and maintaining social distance. This research wanted to know what kind of impolite words found among Makassarese youngsters are and how do the impolite words conversed and exchanged among Makassarese youngsters are.

Online at https://journal.universitasbumigora.ac.id/index.php/humanitatis/

DOI $\quad$ : https://doi.org/10.30812/humanitatis.v8i1.1533 


\section{RESEARCH METHOD}

In this research, the researcher used descriptive qualitative analysis as a research method. The descriptive qualitative method was intended to collect and analyze data. Through this method, the researcher understood and explain profanity among Makassarese youngsters. Moleong (2004) defines a qualitative method as a research procedure that produces descriptive data in the form of words and sentences which fall into the category of profanity uttered by Makassarese youngsters.

The main instruments in this research were observation and interview to Makassarese youngsters. Researcher used interview guidelines, and digital recording. Researcher first asked the willingness of Makassarese youngsters to become participants, whether the youngsters are willing to become participants to in this research or not. Then, the researcher conducted an in-depht interview with the users of impolite language and made important notes from the results of the interview. Researcher also used assistive devices in the form of mobile phones (cellphones) which were uses to record the conversations of researcher and participants.

Observations were conducted eight times. This research was conducted in three different places, namely Jln Barawaja aisle 2, Jln. Pampang Raya, and Jln. Monokwari. The researcher chose three locations as observation sites because these three locations are known as areas where the dominant used of impolite words in everyday life is. Thus, the three locations can support this research. Data collection for each subject was carried out twice, namely recording a video containing two youngsters and recording interviews for each representative of the youngsters in each video recording.

In this research, the sample was Makassarese youngsters who meet certain criteria. The criteria used as research samples are: 1. Participants are Makassarese language users; 2. Participants are categorized as young people; 3 . Participants must be physically and mentally healthy; 4 . Participants are domiciled in the city of Makassar.

The data collecting procedures carried out in this research were: The researcher first made observation to the place where the data were collected and the research object; then, The researcher asked the participants. After they had agreed, the researcher made interview; Then, After collecting the data, the researcher transcripted the recorded results of the speeches of the Makassarese youngsters and the interviews that had been conducted; and the last, the researcher classified the data on the impolite words Makassarese youngsters.

Online at https://journal.universitasbumigora.ac.id/index.php/humanitatis/

DOI : https://doi.org/10.30812/humanitatis.v8i1.1533 


\section{FINDINGS AND DISCUSSION}

This research was conducted by collecting data from human resources, it is Makassarese youngsters. The data was obtained through direct observation in the field and the results of interviews. For the first problem, the researcher classifies the impolite words data in the form of a table. As for the second problem, the data was then presented in descriptive explanation, so that it was easy to be understood and can answer the second problem.

Table 1. Impolite Words Found among Makassarese Youngsters

\begin{tabular}{cc}
\hline Impolite Words & Meaning \\
\hline Sundala, sundallang & Bitch, whore, bastard \\
\hline Tolo & Stupid \\
\hline Kongkong & Dog \\
\hline Pottele & Whore \\
\hline Telang & Vagina \\
\hline Ka'bulamma & Damn it \\
\hline
\end{tabular}

In this research, the data displayed was based on the results of the research that had been done. This research aims to find out what impolite words were used by Makassarese youngsters and the data is shown in detail.

Table 2. Data in $1^{\text {st }}$ Video

\begin{tabular}{ccc}
\hline Participants & Impolite Words & Time \\
\hline DW & Sundala, sundallang & $(00: 02),(00: 11),(00: 21),(01: 26),(01: 31)$, \\
& & $(04: 20),(05: 03),(05: 26)$, \\
\hline & Tolo & $(04: 32),(05: 31),(08: 13)$, \\
\hline NH & - & - \\
\hline SK & - & - \\
\hline
\end{tabular}

This data contains recorded conversations among Makassarese youngsters. Data collection was carried out directly in the field on June 21, 2021. From the minute (8:26) of the video recording which from three participants, two impolite words were found, namely the word sundala and the word tolo. It was found that the use of impolite words such as sundala was repeated 8 times, while the used of impolite words tolo was found repeated 3 times. 
Table 3. Data in $2^{\text {nd }}$ Video

\begin{tabular}{ccc}
\hline Participants & Impolite Words & Time \\
\hline AC & Sundala, sundallang & $(00: 09),(00: 16),(00: 22),(00: 32),(00: 44)$, \\
& & $(00: 52),(01: 04),(01: 15),(01: 29),(01: 34)$, \\
& $(01: 35),(01: 36)$. \\
\hline KR & $(00: 20),(00: 54),(01: 29),(01: 3)$. \\
\hline & Sundala, sundallang & $(00: 10),(00: 19),(00: 29),(00: 33),(01: 20)$. \\
\hline KW & Kongkong & $(00: 20),(00: 54),(01: 29),(01: 31)$. \\
\hline & Sundala, sundallang & $(00: 10),(00: 19),(00: 29),(00: 33),(01: 20)$. \\
\hline
\end{tabular}

This data contains recorded conversations among Makassarese youngsters. Data collection was carried out directly in the field on June 19, 2021. From the second video (1:43), three were theree participants (AC, MR, and DW) who used impolite words. Those words found were sundala, tolo, kongkong, and pottele. sundala was the most repeated in the video. It was repeated seventeen times, and followed by kongkong that was repeated eight time.

Table 4. Data in $3^{\text {rd }}$ Video

\begin{tabular}{ccc}
\hline Participants & Impolite Words & Time \\
\hline TK & - & - \\
\hline DW & Sundala, sundallang & $(00: 16),(00: 18),(00: 26),(00: 49)$. \\
\hline & Telang & $(00: 52),(03: 11)$. \\
\hline WN & ka'bulama & $(04: 25)$. \\
\hline
\end{tabular}

This data contains recorded conversations among Makassarese youngsters. Data collection was carried out directly in the field on June 23, 2021. From the last video (20:08), there were theree participants (TK, DW, and WN) in the third video. The result of video showed that DW is the participants who spoke impolite words the most. She spoken sundala four times, meanwhile, WN only spoke one time during the video, while TK did not speak any impolite words at all.

In this research, the researcher presented data in the form of conversations among Makassarese youngsters to find out how these impolite words were used and exchanged among Makassarese youngsters. Researcher used sociolinguistic studies by taking Brown \& Levinsion's theory of politeness as a theory to analyze the data obtained. Thus, the data on the used of impolite words spoken by Makassarese youngsters are grouped into the Brown and Levinsion strategy which identifies four politeness strategies or general behavior patterns applied by speakers, namely (1) the bald-on record strategy, (2) positive politeness strategies, (3) negative politeness strategies, and (4) off-record politeness strategies.

Theory of the politeness strategy proposed by Brown \& Levinson was based on the concept of face. The politeness strategy was developed in order to save the speaker's "face" or self-image. Therefore,

Online at https://journal.universitasbumigora.ac.id/index.php/humanitatis/ 
it was important to protect the face of yourself or others. Brown and Levinson (1987) identified four politeness strategies or general behavior patterns that can be applied by speakers, namely (1) Bald-on Recorded Strategy, (2) Positive politeness strategy, (3) Negative politeness strategy, (4) Off-recorded politeness strategy. An explanation of each of these politeness strategies is presented in the following sections:

\subsection{Bald-on Recorded Strategy (Without Strategy)}

By using this strategy, speakers do not need to make any efforts to minimize or reduce the consequences of actions that threaten the face or image of the interlocutor. This strategy makes the interlocutor feel shocked, embarrassed and uncomfortable. The used of this strategy was usually used by speakers and interlocutors who already know each other well, for example between friends or among family members. This strategy was usually used to express an emergency.

\section{Conversation 1:}

A: “ca'di ji suara na, ta begituji astagfirullah,, a astagfirulah,, (laughing ) sinampe njo, ana sundala. battu ki sumpaeng, na akkana,, sundala usshh.. !"

In conversation 1, it shows that A used impolite words that threaten the face of the interlocutor as in the sentence "battu ki sumpaeng, na akkana, sundala usshh!". Furthermore, A used impolite words to attract attention so that other participants focus $\mathrm{A}$ as in the sentence

\subsection{Positive Politeness Strategy}

This strategy was used to show familiarity to interlocutors who are not close speakers. To facilitate the interaction, speakers try to give the impression of the same fate and as if they have the same desires as interlocutor and were considered a common desire that was really desired by the same. This strategy was aimed directly at the opponent's positive face. Therefore, the speaker's desire was considered a shared desire between the speaker and the opponent. This strategy also serves as a smoothening of social relationships with other people. By using it, the speaker shows that he wants to be closer to the other person.

In other words, the relationship becomes more intimate and reflects the cohesiveness of the group. This strategy seeks to minimize the distance between speakers and interlocutors by expressing concern and friendship. Thus, the speaker minimizes. Positive politeness strategies are realized in several ways or actions such as focusing on the other person, paying more attention, giving recognition or sympathy to the interlocutor, using group familiarity markers, equating assumptions into public opinion, offering help or promises, and others.

Online at https://journal.universitasbumigora.ac.id/index.php/humanitatis/

DOI : https://doi.org/10.30812/humanitatis.v8i1.1533 


\subsection{Negative Politeness Strategy}

Negative politeness strategies are actions taken to make up for the negative face of the interlocutor and the speaker's desire to be free from burdens with the intention that his actions and intentions were not disturbed and this action was not constrained as the basis for impolite behavior. The main focus of using this strategy was to assume that the speaker was likely to give a burden or a distraction to the interlocutor because he has entered the area of the interlocutor. This politeness strategy was manifested in several ways or actions such as implying, asking questions or evading, being pessimistic, humbling oneself, apologizing, and others.

This politeness strategy was realized in several ways or actions such as: (1) being pessimistic, (2) reducing the burden of requests, (3) humbling oneself, (4) apologizing, (5) placing face threatening actions as a generally accepted rule. Example of Negative politeness strategy (negative politeness strategy/formality) in the conversation of Makassarese youngsters:

C: "jangko ribut! " (be quiet!)

B :"sundallang ko,, memang kau!"(you are really a bitch!)

C : "kenapai tadi ini, di warnet kah ,sodarah?" (what did happen? Are you in warnet?)

A:"itu tadi,, di warnet ka toh ,ada perempuan naik motor, tapi jatuh, na sundala ka!" (I was in warnet, there was a woman, she fell! Damn bitch!)

C:'bukanji, pottele?" (She is a whore, isn't she?)

In conversation above, participants B uses impolite words that place face-threatening actions as a generally accepted rule, namely in the sentence "sundallang ko, memang kau" participants B places the actions taken by participants $\mathrm{A}$ in general, it was like that. Then, the face-threatening action was repeated in the sentence "bukanji, pottele?" which according to the results of the research, the word pottele means prostitute which was included in impolite words. So, in this sentence, participant $\mathrm{C}$ places the word pottele as a face-threatening act as a generally accepted rule

\subsection{Off-recorded Politeness Strategy (Indirect or Disguised Strategy)}

This strategy was manifested in a disguised and way clear communicative intent. With this strategy the speaker brings himself out of the action by letting the interlocutor interpret an action on his own. This strategy was used when the speaker wants to take a face threatening action but does not want to take responsibility for the action. Look at the example:

C: “Agung njo juga, tidak ku suka ki” (I don't like Agung)

A: "Iyo, sundallangi! bawa na, dia mi njo dulu tanya ka, kenapa mauko sama Hendy, tolo!. Nu kenalki, hendy toh putra? Balle balle ko kau, kalau tidak nu kenalki." (I know that bitch! His damn mouth, he asked me if I wanted to go on date with Hendy. Shit! You know him, right, Putra? You are lying if you don't know him)"

Online at https://journal.universitasbumigora.ac.id/index.php/humanitatis/

DOI : https://doi.org/10.30812/humanitatis.v8i1.1533 
In conversation 1, participants A uses the impolite word sundallang to indirectly show how to speak a person named Agung as a negative thing, like in the sentence "iyo, sundallangi! bawa na". Based on the results of the analysis and observations made, it was found that there were some impolite words used by Makassarese youngsters speaking Makassarese and non-Makassarese. Impolite words then, the images displayed in the table where in the table of impolite words are entered only impolite words in Makassarese, impolite words in non-Makassarese are not included in the focus of the research only on Makassarese. Impolite words from the third recorded video that became the source of research data were grouped according to Baryadi (2012) about the characteristics of impoliteness. From the results of the analysis and observation found six words that have impolite characteristics. Those were sundala, konglokong, pottele, tolo, ka'bulamma which are included in the characteristics of impoliteness such as insulting, vilifying, belittling and cursing. Meanwhile, another impolite words found, namely telang, is also an impolite word that contains vulgar elements, which is the genitals or human intimate organs

The used of impolite words among Makassarese youngsters was usually only exchanged between users of impolite words such as between close friends, family or the environment that supports the usedd of these impolite words. The used of impolite words among young Makassarese generally spreads through association among Makassarese youngsters. Although some of them use impolite words from an early age, the researcher realizes that apart from Makassarese youngsters, the used of impolite words in Makassar was not limited by age. Researchers found several places in Makassar that used impolite words from an early age, for example at the age of 13 months. This is inseparable from the environment in which words or languages develop and are exchanged.

\section{CONCLUSION}

The Based on the results of the analysis in this research which has been described by researcher who discuss the analysis of the used of impolite words among Makassarese youngsters using Brown \& Levinsion's politeness theory, here are some conclusion:

First, through the results of grouping the data, the researcher has described in the form of a table. The used of impolite words among Makassarese youngsters includes sundala, kongkong, pottele, tolo, ka'bulamma and telang.

The last, the used of impolite words among Makassarese youngsters was usually exchanged only between users of impolite words such as between close friends, family or the environment that supports the used of these impolite words. The used of impolite words among Makassarese youngsters was

Online at https://journal.universitasbumigora.ac.id/index.php/humanitatis/

DOI : https://doi.org/10.30812/humanitatis.v8i1.1533 
generally used as an opening word or conversation, while the duration of the used of the word starts from the beginning of the conversation until the end of the conversation.

\section{REFERENCES}

Abdelaal, N. M., \& Al Sarhani, A. (2021). Subtitling strategies of swear words and taboo expressions in the movie "Training Day." Heliyon, 7(7), e07351. https://doi.org/https://doi.org/10.1016/j.heliyon.2021.e07351

Acuña Ferreira, V. (2007). 270 pp., ISBN Hb 052181084 1, Pb 052100919 7. Sociolinguistic Studies, 5. Cambridge: Cambridge UniversityPress. https://doi.org/10.1558/sols.v5i1.158

Baryadi, I. P. (2019). Kamus Linguistik. In K. Burridge \& K. Allan (Eds.), Journal of Pragmatics (Vol. 5, Issue No 2). Cambridge $\quad$ University https://doi.org/https://doi.org/10.1016/j.heliyon.2021.e07351

Bousfield, D. (2007). Beginnings, middles and ends: A biopsy of the dynamics of impolite exchanges. Journal of Pragmatics, 2185-2216. https://doi.org/https://doi.org/10.1016/j.pragma.2006.11.005

Burridge, K., \& Allan, K. (Eds.). (2006). Bad language? Jargon, slang, swearing and insult. In Forbidden Words: Taboo and the Censoring of Language (pp. 55-89). Cambridge University Press. https://doi.org/DOI: 10.1017/CBO9780511617881.003

Christie, C. (2006). Gender and Politeness: Sara Mills, Cambridge University Press, Cambridge, 2003, 270 pp., £18.99. Journal of Pragmatics, 38(4), 638-642. https://doi.org/https://doi.org/10.1016/j.pragma.2005.08.001

Culpeper, J., \& Tantucci, V. (2021). The Principle of (Im)politeness Reciprocity. Journal of Pragmatics, 175, 146-164. https://doi.org/https://doi.org/10.1016/j.pragma.2021.01.008

Mahmud, M. (2011). GRAMMATICAL EXPRESSION OF BUGIS POLITENESS. LiNGUA: Jurnal Ilmu Bahasa Dan Sastra, 5. https://doi.org/10.18860/ling.v5i1.618

Mills, S. (2003). Gender and Politeness. In Studies in Interactional Sociolinguistics. Cambridge University Press. https://doi.org/DOI: 10.1017/CBO9780511615238

Piotrowski, M. (2013). Impoliteness. Using Language to Cause Offence: Jonathan Culpeper, Cambridge University Press, Cambridge, 2011, 299 pp., ISBN 978-0-521-68977-9. Journal of Pragmatics, 57, 170-172. https://doi.org/https://doi.org/10.1016/j.pragma.2013.08.010

Rabiah, S. (2018). Revitalisasi Bahasa Daerah Makassar melalui Pengembangan Bahan Ajar Bahasa Makassar sebagai Muatan Lokal. https://doi.org/10.31227/osf.io/bu64e

Tambunsaribu, G. (2019). The Use of Rude Words by Indonesian Teenagers: A Sociolinguistic Case. Proceedings of the International Conference on Interdisciplinary Language, Literature and Education (ICILLE 2018).

Tasliati, T. (2019). Analisis Ketidaksantunan Berbahasa pada Unggahan dalam Grup Daring Jual-beli di Kota Tanjungpinang. Genta Bahtera: Jurnal Ilmiah Kebahasaan Dan Kesastraan, 4, 175-184. https://doi.org/10.47269/gb.v4i2.66

Wyn, J., \& White, R. (1997). Rethinking Youth. https://doi.org/10.4135/9781446250297

Online at https://journal.universitasbumigora.ac.id/index.php/humanitatis/

DOI : https://doi.org/10.30812/humanitatis.v8i1.1533 
Online at https://journal.universitasbumigora.ac.id/index.php/humanitatis/

DOI : https://doi.org/10.30812/humanitatis.v8i1.1533 